\title{
A noninvasive monitoring device for anesthetics in fish
}

This article was published in the following Dove Press journal:

Open Access Animal Physiology

15 June 2010

Number of times this article has been viewed

\author{
Deborah M Power' \\ Juan Fuentes' \\ Adrian P Harrison ${ }^{2}$ \\ 'Centro de Ciências do Mar, \\ Universidade doe Ailgarvme, \\ Portugal; ${ }^{2}$ Section for Physiology \& \\ Biochemistry, IBHV, Faculty of Life \\ Sciences, Copenhagen University, \\ Denmark
}

\begin{abstract}
A noninvasive device capable of recording both gill and lateral fin movements was assembled and used to analyze initial and post-treatment activity frequency $(\mathrm{Hz})$ in fish exposed to anesthetics. Exposure of platy fish (Xiphosphorus maculatus) to saponins from quillaja bark $(0.185 \mathrm{mM}$ and $0.555 \mathrm{mM})$ initially caused hyperactivity, but within five minutes all activity ceased and the fish failed to recover. In contrast, clove oil $(67 \mu \mathrm{g} / \mathrm{L})$ added to water at $22^{\circ} \mathrm{C}$ reduced activity by $22.8 \% \pm 8.9 \%(P=0.038)$ after $125 \pm 19 \mathrm{sec}$, a sedative effect that was totally reversible. Cinnamon oil compared with clove oil had a significantly longer time to sedation $(125 \pm 19$ versus $235 \pm 24 \mathrm{sec}, P=0.02)$, although no significant difference in the decline in activity was noted.
\end{abstract}

Keywords: anesthetics, cinnamon oil, clove oil, platy fish, recording device, teleost

\section{Introduction}

It is generally accepted that anesthesia may be a useful way to maintain fish stress- and injury-free during essential manipulations in aquaculture. ${ }^{1}$ Quite a number of anesthetics have been used or evaluated for use in aquaculture, but issues such as toxicity, safety, and cost are frequently limiting factors. ${ }^{1-6}$ Increased concern about animal welfare and potential suffering caused to aquaculture fish during routine manipulations (eg, handling, medication, and transport) has intensified the search for "good" anesthetics. 7,8

Characterization of the efficacy of anesthetics has generally been carried out by exposure experiments and visual monitoring of the time to sedation and time to recovery, something that could perhaps be mechanized. A range of such studies exist in aquaculture species, such as sea bream (Sparus auratus), white sea bream (Diplodus sargus), sharp snout sea bream (Diplodus puntazzo), sea bass, rock bream (Oplegnathus fasciatus), Senegalese sole (Solea senegalensis), and salmon. ${ }^{9-15}$ These studies reveal that environmental factors, such as water salinity and temperature, and species-specific susceptibility, influence efficacy of anesthetics.

Plant extracts represent a potential source of new anesthetics and have long been used by indigenous tribes of South America and almost every other continent as part of their arsenal of fishing tools. Common toxic piscicides of plant origin include sesquiterpenoids, furanocoumarins, diterpenoids, quinines, and triterpenes. However, the most commonly used piscicides are rotenoids and saponins. Rotenone is known to inhibit NADH-Q reductase in the mitochondrial electron transport chain, and this prevents the mitochondria from using NADH as a substrate. Electron transfer
Correspondence: Adrian P Harrison IBHV, LIFE, Copenhagen University, Grønnegaardsvej 7, I870 Frederiksberg C, Denmark Tel + I I 4535332568

Fax +l I 4535332525

Email adh@life.ku.dk 
is virtually halted, and the organism cannot produce an adequate supply of adenosine triphosphate, which results in asphyxia and paralysis, followed by death. ${ }^{16}$ An anesthetic which has become popular in recent years is the extract of Eugenia caryophyllata, or clove oil, which contains eugenol (2-methoxy-4-2-propenyl phenol), a very effective anesthetic for fish and considered by the US Food and Drug Administration as a generally recognized as safe (GRAS) compound. Cinnamon bark (Cinnamomum zeylanicum) also contains eugenol, but its use as an anesthetic has not been explored.

Thus, the objective of the present study was firstly to develop a noninvasive and automated monitoring device to assess anesthesia in fish, and then subsequently use this device to establish the potential mode of action and identification of new anesthetics for use in fish. To this end, the anesthetic potential of saponins and volatile oils from clove and cinnamon has been determined using the platy fish (Xiphosphorus maculatus).

\section{Material and methods}

\section{Fish}

Adult platy fish, 6-8 cm in length, were purchased from a pet shop and transported in plastic bags insulated with paper to the experimental facility (Section for Physiology and Biochemistry, Faculty of Life Sciences, Copenhagen University). Fish ( $n=6 /$ tank) were acclimated to $10 \mathrm{~L}$ glass containers containing dechlorinated tap water at $22^{\circ} \mathrm{C}$ and a photoperiod of approximately 16 hours light and eight hours dark (May in Denmark, sunrise 04:45 hours and sunset 21:30 hours) and allowed a 48-hour period to recover from the stress of transportation and handling. The water had a documented quality comprising oxygen $10.7 \mathrm{mg} / \mathrm{L}$, an iron content of $0.006 \mathrm{mg} / \mathrm{L}, \mathrm{pH} \mathrm{7.6}$, and a conductivity of $66.3 \mathrm{mS} / \mathrm{m}$. Tanks were cleaned daily and $50 \%$ of tank water substituted every three days. The fish were fed twice daily to satiety with TetraMin ${ }^{\circledR}$ (Tetra GmbH, Melle, Germany) comprising crude protein $48 \%$, crude fat $8 \%$, crude fiber $2 \%$, ash $11 \%$, moisture content $6 \%$, and vitamins. Experiments were carried out during May 2007.

The study was conducted in compliance with the European Community guidelines (86/609/EU) concerning the protection of experimental animals, and in accordance with local national guidelines for animal experimentation.

\section{Activity measurements}

A noninvasive recording device, comprising three copper electrodes, was assembled in a $300 \mathrm{~mL}$ glass tank in order to monitor and record fish activity accurately (see Figure 1). The device was capable of recording both gill and lateral fin movements, which were then analyzed in terms of initial and post-treatment activity frequency $(\mathrm{Hz})$. Activity signals were recorded via an ML 132 amplifier connected to a ML 780 PowerLab/8S A/D converter connected to an iBook G4 running Chart5 v.5.4 Software (AD Instruments, Australia). The data recording was at a sampling speed of 40,000 data samples per second $(40 \mathrm{kHz})$ and the input impedance of the amplifier was $200 \mathrm{~m} \Omega$ differential. Decline in activity was defined as being either or both a reduction in signal amplitude ( $\mathrm{mV}$, constituting less powerful fin and gill movements), or signal frequency $(\mathrm{Hz}$, constituting an increase in time between repeated movements of fins and gills).

\section{Clove, cinnamon oil, and saponins}

Commercially available cinnamon and clove oils were used in this study (Urtegaarden Aps, Allingåbro, Denmark), and their action was compared with that of saponins. Clove oil extract imported from Indonesia, was derived from the flowering buds of E. caryophyllata, and was $100 \%$ pure. Cinnamon oil extract imported from China, was derived from the bark of C. cassia, and was also $100 \%$ pure. A standard solution was prepared of purified saponin from quillaja bark $(1 \mathrm{mg} / \mathrm{mL}$ distilled water; Sigma-Aldrich, Denmark).

\section{Analytical procedure}

Recording of activity was carried out in a $300 \mathrm{~mL}$ volume tank containing $150 \mathrm{~mL}$ of water at a constant temperature $\left(22^{\circ} \mathrm{C}\right)$. Preliminary experiments were carried out to optimize the setup of the recording system and to establish an approximate dose range of clove and cinnamon oil appropriate for sedation of platy fish (only opercula movements visible). The initial experiments linked results of instrument recordings to visually evaluated states of anesthesia in the fish, ie, partial loss of equilibrium and erratic swimming, mild sedation (slowed opercula, and anal fin and tail fin movement), and sedation (very slow/irregular opercula and fin movements). ${ }^{1}$ Recovery time was evaluated as being the time taken to recover normal swimming and responsiveness to visual stimuli upon removal to a recovery tank containing clean water. Food was withheld from the fish on the day of the experiment.

For studies of the anesthetics, fish were placed in the recording system and given time to settle (approximately five minutes) before initiating recording. Activity was recorded for approximately one minute prior to adding the test anesthetic, which was prepared fresh in $5 \mathrm{~mL}$ of 


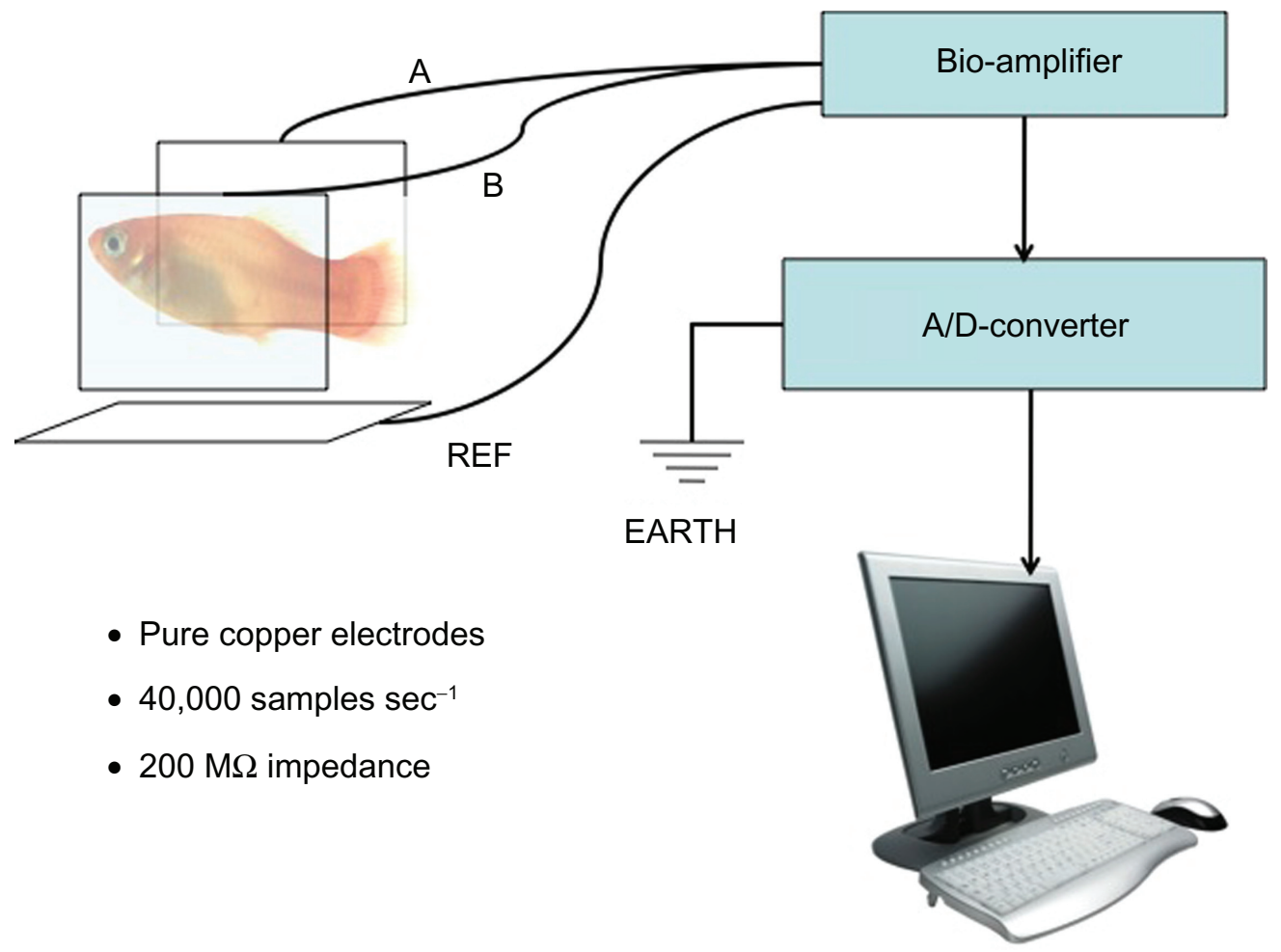

Figure I A schematic of the noninvasive recording device used to record both gill and lateral fin movements in platy fish. The pure copper electrode (A, B, and reference) were connected to a ML 132 Bioamplifier, connected to a ML 780 PowerLab/8S A/D converter, connected to an iBook G4 running Chart 5 vs 5.4 Software (AD Instruments, Australia). Data collection was achieved by means of a double-differential array, in which the signal from electrode B was subtracted from that obtained from electrode $A$, before finally being corrected for any "background" noise within the system, sensed through the third reference electrode. The data recording was at a sampling speed of 40,000 data samples per second $(40 \mathrm{kHz})$, giving very smooth and precise measurements of individual "spikes/movements", and the input impedance of the amplifier was $200 \mathrm{~m} \Omega$ differential.

water at $22^{\circ} \mathrm{C}$ and vigorously mixed immediately prior to experimentation. To minimize disturbance of fish, the anesthetic (final concentration: clove oil $0.67 \mu \mathrm{g}, 6.7 \mu \mathrm{g}$, $33.5 \mu \mathrm{g}$, or $67 \mu \mathrm{g} / \mathrm{L}$, or cinnamon oil $0.67 \mu \mathrm{g}, 6.7 \mu \mathrm{g}$, $33.5 \mu \mathrm{g}$, or $67 \mu \mathrm{g} / \mathrm{L}$ was added to one corner of the experimental tank containing $145 \mathrm{~mL}$ of dechlorinated tap water using a $5 \mathrm{~mL}$ pipette and mixed by rapidly pipetting up and down. Evaluation of the anesthetic effect of purified saponin from quillaja bark was carried out by adding 15 , 50 , and $150 \mathrm{mg}$ dissolved in $5 \mathrm{~mL}$ of distilled water to the experimental tank $(150 \mathrm{~mL}$ volume, ie, approximately $0.055 \mathrm{mM}, 0.185 \mathrm{mM}$, and $0.555 \mathrm{mM}$, respectively) and mixing vigorously as described above.

To assess the possible site of action of clove oil, a second group of experiments was carried out with Ruthenium red $\left(\mathrm{Ru}_{2} \mathrm{OH}_{2} \mathrm{Cl}_{4} \cdot 7 \mathrm{NH}_{3} .3 \mathrm{H}_{2} \mathrm{O}\right.$, Number $12319,99 \%$ purity; Merck, Denmark), a noncompetitive vanillin receptor antagonist, at a final concentration of $15 \mu \mathrm{M}$. Fish were pre-exposed in the experimental circuit to Ruthenium red for five minutes before addition of the test anesthetic. Fish activity was recorded prior to and during exposure to Ruthenium red, and during subsequent exposure to test anesthetics.

\section{Statistics}

Data are presented as mean \pm standard error of measurement (SEM). Differences between means were tested for statistical significance with the use of GraphPad Instat 3 for Mac (version 3.0b, 2003; GraphPad Inc., La Jolla, CA), with an additional test for Gaussian normal distribution. Data that were normally distributed according to a Kolmogorov and Smirnov test, and having an equal variance, were tested for significant difference between means using a $t$-test. Otherwise a Mann-Whitney nonparametric analysis was performed. Differences showing a $P$ value $<0.05$ were considered significant (Table 1 ).

\section{Results}

\section{Recording device}

The system used for recording fish activity (defined as being opercula movements as well as fin movements), proved very sensitive in terms of its ability to record both unipolar and bipolar signals (see Figure 2). Typically, background electrical noise was in the order of magnitude of $0-2 \mu \mathrm{V}$ (amplitude of oscillating signal), whilst extremely small opercula and fin movements yielded a signal with an amplitude of at least $10 \mu \mathrm{V}$. Indeed, usually the recordings had 


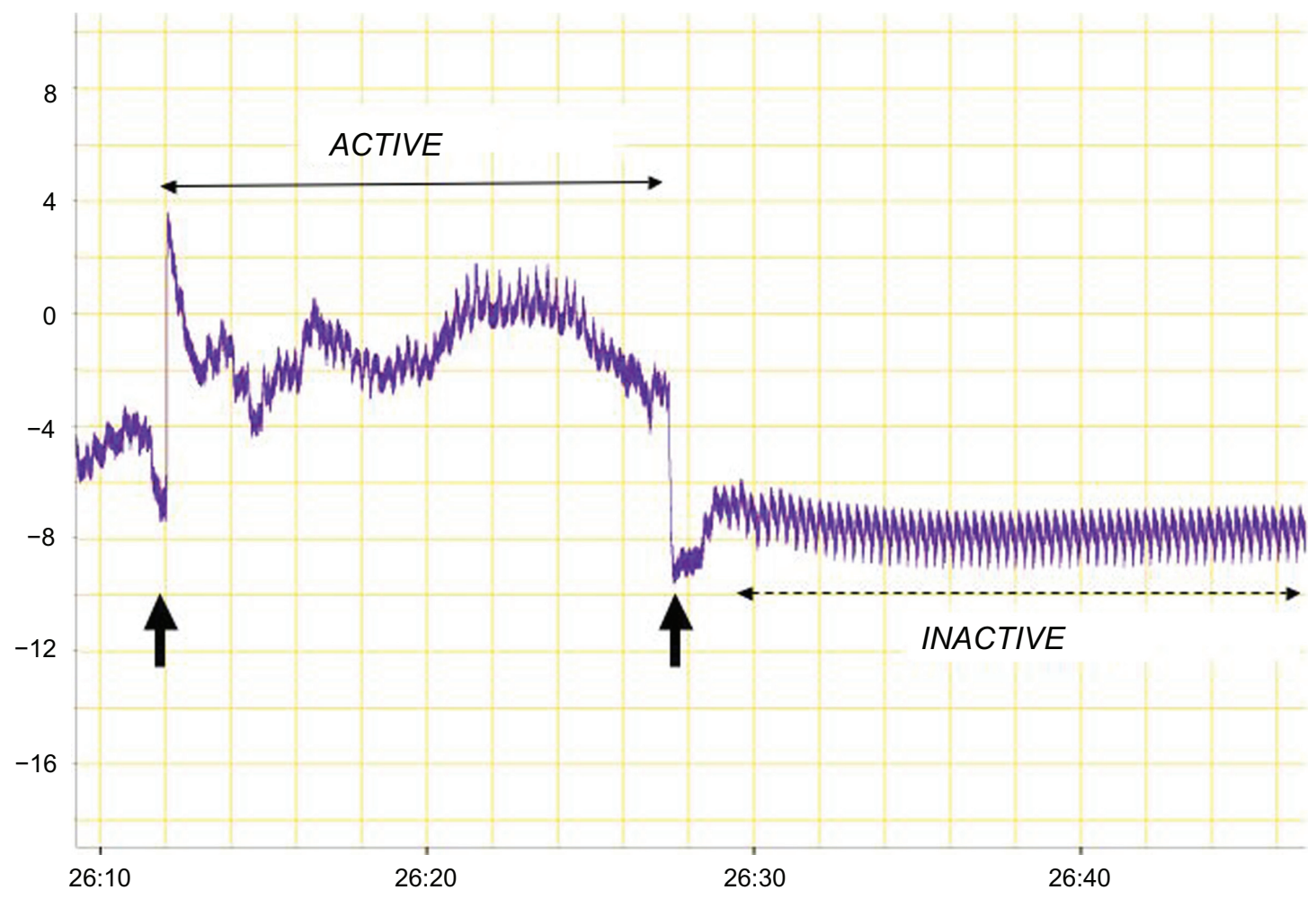

Figure 2 A typical recording of both gill and lateral fin movements, which were then analyzed in terms of the initial and post-treatment activity frequency (Hz) of platy fish. Note that the recordings denoted by $\uparrow$ indicate an $180^{\circ}$ turn by the platy fish within the recording chamber. The region of the recording denoted by a solid two-arrow line represents a period of active movement by the fish (unstable baseline and irregular spikes), whilst the region denoted by the dotted two-arrow line represents a stable period of inactivity measuring gill and fin activity $(3.6 \mathrm{I} \mathrm{Hz})$ alone. The $y$-axis = activity $(\mathrm{mV})$ and $\mathrm{x}$-axis = time $(\mathrm{sec})$.

an amplitude of $23-26 \mu \mathrm{V}$, giving a signal to noise ratio of 11.5:1-13:1.

\section{Analytical procedure}

Saponin

Saponin from quillaja bark $(0.185 \mathrm{mM}$ and $0.555 \mathrm{mM})$ was tested on platy fish $(n=4-6)$ and initially caused hyperactivity, but within five minutes of exposure all activity ceased and fish died very suddenly. All of the concentrations tested caused death and no further studies were carried out.

\section{Clove and cinnamon oils}

Clove oil (33.5 or $67 \mu \mathrm{g} / \mathrm{L}$ ) had a rapid action and totally reversible effect, and sedated fish within two minutes of exposure. Activity, as determined by fin movements, gave a good index of anesthetic effect, and dropped significantly $(22.8 \% \pm 8.9 \%$ decline, $P=0.038)$ after $125 \pm 19 \mathrm{sec}$ in fish exposed to clove oil. An additional dilution of clove oil resulted in a significantly longer time to sedation (125 \pm 19 versus $530 \pm 33 \mathrm{sec}$ for 33.5 and $67 \mathrm{mg} / \mathrm{L}$ versus $6.7 \mu \mathrm{g} / \mathrm{L}$, respectively, $P=0.004$ ), without any further significant decline in activity. Further dilutions of clove oil $(0.67 \mu \mathrm{g} / \mathrm{L})$ caused an initial period of hyperactivity, which was followed by reduced activity and fish never reached a state of total sedation.

Cinnamon oil $(67 \mu \mathrm{g} / \mathrm{L})$ also had a fairly rapid action and totally reversible effect and sedated fish within four minutes of exposure. After preliminary testing $(0.67-67 \mu \mathrm{g} / \mathrm{L})$ in order to optimize the concentration of cinnamon oil needed to produce reversible anesthesia, a comparison of clove oil $(67 \mu \mathrm{g} / \mathrm{L})$ versus cinnamon oil $(67 \mu \mathrm{g} / \mathrm{L})$ revealed a significantly longer time to sedation $(125 \pm 19$ versus $235 \pm 24 \mathrm{sec}, P=0.02$ ), although no significant difference in decline in activity was noted. Finally, cinnamon oil was noted to cause an initial period of hyperactivity, which was followed by reduced activity, similar to that found with low concentrations of clove oil $(0.67 \mu \mathrm{g} / \mathrm{L})$.

\section{Ruthenium red and clove oil}

Incubation of platy fish for a relatively short period of four minutes in a $15 \mu \mathrm{M}$ Ruthenium red aqueous solution had no detrimental effect on the anesthetic effect of $67 \mu \mathrm{g} / \mathrm{L}$ clove oil in water, because platy fish were completely motionless after approximately 125 seconds. After a much longer 30 minute incubation of platy fish in a $15 \mu \mathrm{M}$ Ruthenium red aqueous solution, no adverse effects were noted. On addition 
Table I Summary of results, highlighting the type of compound tested, the concentration applied, the time recorded to sedation, reversibility, and any statistically significant difference between individual compounds and concentrations*

\begin{tabular}{|c|c|c|c|c|}
\hline Compound & Concentration & $\begin{array}{l}\text { Time to } \\
\text { sedation (sec) }\end{array}$ & Reversibility & Statistical significance \\
\hline A: Quillaja bark saponin & $0.185 \mathrm{mM}$ & $<300$ & No - death & $\mathrm{N} / \mathrm{A}$ \\
\hline A: Quillaja bark saponin & $0.555 \mathrm{mM}$ & $<300$ & No - death & $N / A$ \\
\hline B: Clove oil & $33.5 \mu \mathrm{g} / \mathrm{L}$ & 125 & Yes & $\mathrm{N} / \mathrm{A}$ \\
\hline B: Clove oil & $67.0 \mu g / L$ & 125 & Yes & NS versus $33.5 \mu \mathrm{g} / \mathrm{L}$ \\
\hline B: Clove oil & $6.7 \mu g / L$ & 530 & Yes & $\begin{array}{l}P=0.004 \text { versus } 33.5 \mu \mathrm{g} / \mathrm{L} \\
\text { and } 67.0 \mu \mathrm{g} / \mathrm{L} \text { clove oil }\end{array}$ \\
\hline B: Clove oil & $0.67 \mu g / L$ & No sedation & Yes & $\mathrm{N} / \mathrm{A}$ \\
\hline C: Cinnamon oil & $67.0 \mu \mathrm{g} / \mathrm{L}$ & $<240$ & Yes & $\begin{array}{l}P=0.02 \text { versus } 67.0 \mu \mathrm{g} / \mathrm{L} \\
\text { clove oil }\end{array}$ \\
\hline C: Cinnamon oil & $0.67 \mu \mathrm{g} / \mathrm{L}$ & No sedation & Yes & $\mathrm{N} / \mathrm{A}$ \\
\hline D: Ruthenium red & $\begin{array}{l}15 \mu \mathrm{M} \text { for } 30 \text { min with } \\
6.7 \mu \mathrm{g} / \mathrm{L} \text { clove oil }\end{array}$ & No sedation at 900 & Yes & $\mathrm{N} / \mathrm{A}$ \\
\hline
\end{tabular}

Note: "For details of statistical tests see Materials and methods section.

Abbreviation: N/A, not applicable.

of clove oil $(67 \mu \mathrm{g} / \mathrm{L})$, full anesthesia was achieved within 290 seconds. However, in a repeat experiment in which a lower dose of clove oil was administered $(6.7 \mu \mathrm{g} / \mathrm{L})$ and a similar 30-minute equilibration period in Ruthenium red $15 \mu \mathrm{M}$ was used, and no signs of anesthesia were noted even after 15 minutes.

\section{Discussion}

This study, which is the first to design and test a noninvasive device capable of recording both gill and lateral fin movements, has examined the efficacy of a number of natural anesthetics on platy fish.

\section{Recording device}

The choice of copper electrodes in this recording system gave a much cleaner signal in terms of background noise than that obtained using stainless steel electrodes (data not shown). However, a far cleaner and more sensitive recording device could be assembled if 24 carat gold or pure platinum electrodes had been used. The use of such "noble metals" as electrodes would also facilitate the application of this device with salt-water fish. Moreover, the flat nature of the recording electrodes lends itself to use with flatfish, provided an electrode were placed below and above the fish, and contact between the fish and the electrodes were prevented by means of a plastic net or gauze.

\section{Secondary plant metabolites as piscine anesthetics}

Plant poisons, which are often saponin-based, are still in use by indigenous tribes in many places in the world today.
Furthermore, reports indicate that whilst saponins can be powerful poisons, they are not usually fatal, and fish that are washed in untainted water often revive fully and return to their pretoxin condition. ${ }^{17}$ One of the ways in which saponins act is via hemolysis of red blood cells in the fish, and in the present study this occurred slowly (results not shown), suggesting that impairment of respiratory capacity in exposed fish might be expected to be slight. It seems probable that saponins "stunned" fish rather than anesthetized them, a proposal supported by reports that fishermen using saponins need to gather fish quickly as they float to the surface because they recover rapidly. ${ }^{17}$ Their results indicate that saponins and related compounds can be excluded from the list of potential new anesthetics, although their role as a calmative agent may warrant closer investigation, particularly as they are reported to have no adverse effect on the flavor or edibility of the fish.

Clove bud oil comprises a number of volatile oils, totaling $15 \%-18 \% \mathrm{v} / \mathrm{w}$. Of these volatile oils, eugenol represents some $80 \%-90 \%$, eugenyl acetate represents $2 \%-27 \%$, and $\beta$-caryophyllene represents $5 \%-12 \%$. In contrast, cinnamon bark comprises less volatile oil, totaling approximately $4 \% \mathrm{v} / \mathrm{w}$. Of these volatile oils, cinnamaldehyde represents some $60 \%-75 \%$ and phenols represent $4 \%-10 \%$, of which eugenol, methyl eugenol, and safrole are components. Of the various types of cinnamon bark, the oil of C. zeylanicum is stated to contain the highest amount of eugenol. Moreover, cinnamon leaf oil is reported to contain far higher concentrations of eugenol, ie, $80 \%-96 \%$, depending on species.

At present we are unable to explain the difference in time to sedation with cinnamon versus clove oil, although it may be 
due to differences in eugenol content, or other as yet unidentified active components of the oils. A closer investigation of these two oils in terms of their composition is now required if this particular observation is to be explained. In addition, future studies should also focus on the degree to which these oils can be used repeatedly to sedate fish, as previous studies have noted that desensitization to eugenol and/or other compounds within the oils occurs over time. ${ }^{9}$ The dose of cinnamon or clove oil required for anesthesia in the present study was significantly lower than those reported in previous studies (range 4-150 mg/L) using aquaculture species, but this is probably a consequence of the anesthetic endpoint chosen, species, water temperature, and other factors previously described to influence anesthesia. ${ }^{9,10,12-15,18-21}$

\section{Potential mode of action of eugenol}

Eugenol, the major component of the essential oils of clove and cinnamon, has been used to relieve pain arising from a variety of sources. ${ }^{22}$ Eugenol $\left(\mathrm{C}_{10} \mathrm{H}_{12} \mathrm{O}_{2}\right)$ is an allyl chain-substituted guaiacol which acts in both the pre- and postsynaptic sites of neurons by blocking the $\mathrm{Ca}^{2+}$ current, decreasing membrane potential, and decreasing gamma aminobutyric acid, acetylcholine, and glutamate-evoked excitatory responses at submillimolar concentrations. ${ }^{23}$ The fact that eugenol, as a natural capsaicin congener, also contains vanillin-moiety-like capsaicin suggests that eugenol may act on vanillin receptor 1 (a transient receptor potential ion family channel), as capsaicin does in sensory neurons. ${ }^{24-26}$ In the present study, the rather incomplete effect of the vanillin receptor 1 noncompetitive antagonist, Ruthenium red, suggests that other receptors are also affected by eugenol. It is therefore important to determine whether a high concentration of eugenol is capable of acting via other receptors, with a "poorer fit" pharmacologically, to impair the effectiveness of Ruthenium red.

\section{Conclusion}

It is concluded that the recording device assembled in this study can be used successfully to record anesthetic effects on platy fish, and indeed could be readily adapted to measure anesthetic effects in juvenile aquaculture species too. The results of the present study indicate that saponins are not effective as a fish anesthetic but that clove oil, as previously reported, and cinnamon oil, offer a safe alternative to current anesthetics, sedating fish in a reversible fashion within $125 \pm 19 \mathrm{sec}$ and $235 \pm 24 \mathrm{sec}$ for clove and cinnamon oils, respectively. Moreover, studies with Ruthenium red suggest that part of the anesthetic effect of clove oil is through the vanillin receptor 1 , but that other mechanisms are also involved. It is therefore proposed that the recording device developed be adopted as a reliable, rapid, and noninvasive method for monitoring the efficacy of anesthetics in fish where other monitoring systems are too labor-intensive or unsuitable.

\section{Acknowledgments}

We appreciate the dedication and skilled technical assistance of Birgitte Holle. DMP acknowledges the support of an STMS exchange grant funded in the context of COST 925 action.

\section{References}

1. Summerfelt RC, Smith LS. Anaesthesia, surgery and related techniques. In: Schreck CB, Moyle PB, editors. Methods in Fish Biology. Bethesda, MD: American Fisheries Society; 1990.

2. Marking LL, Meyer FP. Are better anesthetics needed in fisheries? Fisheries. 1985;10:2-5.

3. Gilderhus PA, Marking LL. Comparative efficacy of 16 anesthetic chemicals on rainbow trout. North Am J Fishery Manag. 1987;7:288-292.

4. Iwama GK, McGeer JC, Pawluk MP. The effects of five fish anaesthetics on acid base balance, hematocrit, blood gases and adrenaline in rainbow trout. Can J Zool. 1989;67:2065-2073.

5. Stoskopf M. Anaesthesia. In: Brown L, editor. Aquaculture for Veterinarians. Oxford, UK: Pergamon Press; 1993.

6. Ross LG, Ross B. Anaesthetic and Sedative Techniques for Aquatic Animals. London, UK: Blackwell Science Ltd; 1999.

7. Ashley PJ. Fish welfare: Current issues in aquaculture. Appl Anim Behav Sci. 2007;104:199-235.

8. Southgate PJ. Welfare of fish during transport. In: Branson EJ, editor. Fish Welfare. Oxford: Blackwell Publishing; 2008.

9. Mylonas CC, Cardinaletti G, Sigelaki I, Polzonetti-Magni A. Comparative efficacy of clove oil and 2-phenoxyethanol as anesthetics in the aquaculture of European sea bass (Dicentrarchus labrax) and the gilthead sea bream (Sparus aurata) at different temperatures. Aquaculture. 2005;246:467-481.

10. Tsantilas H, Galatos AD, Athanassopoulou F, Prassinos NN, Kousoulaki K. Efficacy of 2-phenoxyethanol as an anaesthetic for two size classes of white sea bream, Diplodus sargus L, and sharp snout sea bream, Diplodus puntazzo C. Aquaculture. 2006;253:64-70.

11. Park MO, Im SY, Seol DW, Park IS. Efficacy and physiological responses of rock bream, Oplegnathus fasciatus to anesthetization with clove oil. Aquaculture. 2009;287:427-430.

12. Bourne PK. The use of MS222 (tricaine methanesulphonate) as an anaesthetic for routine blood sampling in three species of marine teleosts. Aquaculture. 1984;36:313-321.

13. Weber RA, Peleteiro JB, Garcia-Martin LO, Aldegunde M. The efficacy of 2-phenoxyethanol, metomidate, clove oil and MS-222 as anaesthetic agents in the Senegalese sole (Solea senegalensis Kaup 1858). Aquaculture. 2009;288:147-150.

14. Woody CA, Nelson J, Ramstad K. Clove oil as an anaesthetic for adult sockeye salmon: Field trials. J Fish Biol. 2002;60:340-347.

15. Iverson M, Eliassen RA, Finstad B. Potential benefit of clove oil sedation on animal welfare during salmon smolt, Salmo salar L. transport and transfer to sea. Aquaculture Res. 2009;40:233-241.

16. Neuwinger HD. Fish poisoning plants in Africa. Bot Acta (Germany). 1994:107;263-270.

17. Kritzon C. Fishing with poisons. Bull Primitive Technol. 2003. Available from: http://www.primitive.org/backissues.htm Accessed May 17, 2010. 
18. Soto CG, Burhanuddin S. Clove oil as a fish anesthetic for measuring length and weight of rabbit fish (Siganus lineatus). Aquaculture. 1995;136:149-152.

19. Keene JL, Noakes DLG, Moccia RD, Soto CG. The efficacy of clove as an anesthetic for rainbow trout Oncorhynchus mykiss (Walbaum). Aquatic Res. 1998;29:89-101.

20. Kildea MA, Allan GL, Kearney RE. Accumulation and clearance of the anesthetics clove oil and AQUI-S ${ }^{\mathrm{TM}}$ from the edible tissue of silver perch (Bidyanus bidyanus). Aquaculture. 2004;232:265-277.

21. Ribas L, Flos R, Reig L, MacKenzie S, Barton BA, Tort L. Comparison of methods for anaesthetizing Senegal sole (Solea senegalensis) before slaughter: Stress response and final product quality. Aquaculture. 2007; 269:250-258.

22. Sneddon IB, Glew RC. Contact dermatitis due to propanidid in an anaesthetist. Practitioner. 1973;211:321-323.
23. Szabadics J, Erdelyi L. Pre- and postsynaptic effects of eugenol and related compounds on Helix pomatia L. neurons. Acta Biol Hungarian. 2000;51:265-273.

24. Szallasi A, Blumberg PM. Vanilloid (capsaicin) receptors and mechanisms. Pharmacol Rev. 1999;51:159-212.

25. Caterina MJ, Schumacher MA, Tominaga M, Rosen T, Levine JD, Julius D. The capsaicin receptor: A heat-activated ion channel in the pain pathway. Nature. 1997;389:816-824.

26. Helliwell RJ, McLatchie LM, Clarke M, Winter J, Bevan S, McIntyre P. Capsaicin sensitivity is associated with the expression of the vanilloid (capsaicin) receptor (VR1) mRNA in adult rat sensory ganglia. $\mathrm{Neurosci}$ Lett. 1998;250:170-180.

\section{Publish your work in this journal}

Open Access Animal Physiology is an international, peer-reviewed, open access journal publishing original research, reports, reviews and commentaries on all areas of animal physiology. The manuscript management system is completely online and includes a very

\section{Dovepress}

quick and fair peer-review system. Visit http://www.dovepress.com/ testimonials.php to read real quotes from published authors. 